\title{
RETENTION OF ALUMINUM ION AND HYDROGEN ION IN PAPERS
}

\author{
By Herbert F. Launer
}

\section{ABSTRACT}

The decrease in $\mathrm{pH}$, observed when paper-water mixtures are heated and then cooled, was found to be ascribable to the increased hydrolysis of the aluminum salts in the papers. Studies of fiber-alum-water mixtures showed that aluminum ion is selectively retained by the fibers, and that the amount of aluminum salts in papers is thus much larger than that calculated solely from the concentrations involved in the manufacture of papers. It was found that the fibers raise the $\mathrm{pH}$ of alum solutions to which they have been added by an amount which is characteristic of the type of fiber and of the concentration of the alum, aluminum sulfate. It is also shown that the change in $\mathrm{pH}$ upon heating such mixtures is likewise determined by the type of fiber and the concentration of the alum. Hydrogen ion is also strongly retained by fibers in an amount shown to be unchanged after heating and cooling. The effect of rosin upon $\mathrm{pH}$ relationships in papers is also discussed.

\section{CONTENTS}

Page

I. Introduction

II. Relationship between changes in $\mathrm{pH}$ by hot extraction and amounts of alum used in paper manufacture. 664

III. Effect of acids from sources other than hydrolysis of aluminum salts_._. 665

IV. Behavior of alum solutions in the presence of fibers

V. Retention phenomena under papermaking conditions

VI. Effect of rosin upon $\mathrm{pH}$ relationships

VII. Fudamental basis for choosing between hot extraction and cold extraction

\section{INTRODUCTION}

In a recent publication ${ }^{1}$ dealing with the determination of the $\mathrm{pH}$ values of papers by the method of cold extraction, it was found that these values were usually higher, by $0.6 \mathrm{pH}$, on the average, than those obtained when extraction was made at $100^{\circ} \mathrm{C}$, as in the TAPPI ${ }^{2}$ standard method. An explanation for the cause of this difference was not given at that time, as the main efforts were devoted to finding whether the simpler method of cold extraction was preferable from a practical standpoint. In the present article a study of the underlying causes of this difference is presented.

Investigators have previously studied the effects of hot extraction. Browning and Ulm ${ }^{3}$ have shown that hot extraction gives lower $\mathrm{pH}$ values than cold extraction and ascribe this in part to the increased

\footnotetext{
1 Herbert F. Launer, The determinetion of the $\mathrm{pH}$ value of papers, J. Research NBS 22, 553 (1939) RP1205. - Technical Association of the Pulp and Paper Industry-T435m, Hydrogen ion concentration (pH) of paper extracts, September 6, 1934. Copies may be obtained from the Association, 122 East $42 \mathrm{~d}$ Street, New York, N. Y.

B. L. Browning and R. W. K. Ulm, Paper Trade J. 102, 89 (Feb. 20, 1936).
} 
hydrolysis of alum, $\mathrm{Al}_{2}\left(\mathrm{SO}_{4}\right)_{2} \cdot 18 \mathrm{H}_{2} \mathrm{O}$, added in the course of papermaking. Kullgren ${ }^{4}$ found that the hydrolysis of $\mathrm{AlCl}_{3}$ in a $0.002 \mathrm{~N}$ solution increased tenfold upon raising the temperature from $25^{\circ}$ to $100^{\circ}$ C. Furthermore, Heyrovsky ${ }^{5}$ found that the reversal of this hydrolysis reaction takes place slowly, and that $\mathrm{AlCl}_{3}$, the hydrolysis of which had been increased by heating, remained in that condition long after cooling.

In discussing another possible explanation of the effect of heating, Browning and UTm point out the possibility that sulfuric acid, which arises from the hydrolysis of alum, and which acid they assume is adsorbed by the fibers in the cold, may be released upon heating, thus lowering the $\mathrm{pH}$. It has not yet been conclusively shown, however, that sulfuric acid is adsorbed under the conditions of extraction, that is, under the same conditions of concentration and temperature. They also give titration curves which show that weak organic acids are present in the extract. No evidence has been presented, however, as to what extent organic acids formed during the hot extraction contribute to the measured $\mathrm{pH}$. Since the $\mathrm{pH}$ may be affected by liberation of adsorbed sulfuric acid, if any, or formation of organic acids, or both, by heating, it is necessary to determine the magnitude of these effects before dealing with any other possible effects of heating.

Furthermore, Browning and Ulm observed that a solution of alum did not change in $\mathrm{pH}$ upon heating when sulfite fibers were present, although large $\mathrm{pH}$ changes occurred in the absence of the fibers. This points to a complexity which is greater than the behavior of simple alum solutions, and an explanation for this apparent discrepancy is offered herein.

Finally, it is important to decide whether the amount of hydrolyzable aluminum salt in the finished paper is simply the amount in the paper-machine solution held by the fibers $(1 \mathrm{~g}$ of fibers holds $1.5 \mathrm{~g}$ of paper-machine solution before entering the machine dryers), or whether the amount of aluminum is actually much larger than this, by virtue of its selective retention by the fibers in the beater and chest.

It was believed that a study of these points would not only provide a fundamental basis for choosing between the two methods of extraction, but would also add to existing information concerning the chemistry of paper.

\section{RELATIONSHIP BETWEEN CHANGES IN pH BY HOT EXTRACTION AND AMOUNTS OF ALUM USED IN PAPER MANUFACTURE}

For the sake of clarity, a part of the experimental results presented in the previous publication (see footnote 1) is shown in table 1. As was previously pointed out, the similarity of changes in $\mathrm{pH}$, column 7 , is misleading in that it shows little with regard to acidity changes. When these are expressed as changes in hydrogen-ion concentration, column 8 , the correlation with the amounts of alum, column 4 , indicates strongly that the acidity changes occurring upon heating the paper-water extracts are dependent upon the amounts of alum used in making the papers, except for smaller effects such as amount of alkaline rosin size and type of fiber. This correlation and the factors affecting it were discussed in the previous publication.

4 Carl Kullgren, Z. physik. Chem. 85, 466 (1913).

S Jaroslav Heyrovsky, J. Chem. Soc. 11\%, 11, 29 (1920). 
TABLE 1.-Relations between the acidity values and other characteristics of the papers

\begin{tabular}{|c|c|c|c|c|c|c|c|c|c|}
\hline 1 & 2 & 3 & 4 & 5 & 6 & 7 & 8 & 9 & 10 \\
\hline $\begin{array}{l}\text { Sample } \\
\text { number }\end{array}$ & Fibers & $\begin{array}{l}\text { Resin } \\
\text { found }\end{array}$ & $\begin{array}{l}\text { Alumb } \\
\text { used } \\
\text { in } \\
\text { paper- } \\
\text { making }\end{array}$ & $\begin{array}{l}\text { pH, } \\
\text { using } \\
\text { cold } \\
\text { extrac- } \\
\text { tion }\end{array}$ & $\begin{array}{l}\text { pH, } \\
\text { using } \\
\text { hot } \\
\text { extrac- } \\
\text { tion }\end{array}$ & $\begin{array}{l}\text { pH, } \\
\text { change } \\
\text { upon } \\
\text { heat- } \\
\text { ing }\end{array}$ & $\begin{array}{l}\left(\mathrm{H}^{+}\right) \\
\text {change } \\
\text { upon } \\
\text { heat- } \\
\text { ing }\end{array}$ & $\begin{array}{l}\text { (H+), } \\
\text { using } \\
\text { cold } \\
\text { extrac- } \\
\text { tion }\end{array}$ & $\begin{array}{l}\text { pH, } \\
\text { change } \\
\text { upon } \\
\text { heating } \\
\text { filtrates }\end{array}$ \\
\hline 6 & $\begin{array}{l}\text { New rags } \\
\text { do } \\
\text { do }\end{array}$ & $\begin{array}{r}\text { Percent } \\
0.9 \\
1.7 \\
0.9 \\
1.7 \\
0.2 \\
1.8 \\
0.9 \\
1.6 \\
0.3 \\
.8 \\
.3\end{array}$ & \begin{tabular}{|r} 
Percent \\
4.0 \\
4.0 \\
2.0 \\
2.0 \\
1.5 \\
1.2 \\
1.1 \\
0.9 \\
.8 \\
.7 \\
.5
\end{tabular} & $\begin{array}{l}4.9 \\
5.1 \\
5.2 \\
5.4 \\
5.5 \\
5.6 \\
5.6 \\
6.4 \\
6.4 \\
6.3 \\
7.2\end{array}$ & $\begin{array}{l}4.3 \\
4.4 \\
4.5 \\
4.7 \\
4.9 \\
5.0 \\
5.0 \\
5.9 \\
6.0 \\
6.0 \\
7.3\end{array}$ & $\begin{array}{r}0.6 \\
.7 \\
.7 \\
.7 \\
.6 \\
.6 \\
.6 \\
.5 \\
.4 \\
.3 \\
\end{array}$ & 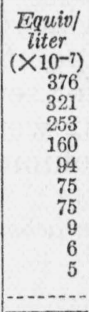 & $\begin{array}{r}\text { Equiv/ } \\
\text { liter } \\
\left(\times 10^{-7}\right) \\
126 \\
79 \\
63 \\
40 \\
32 \\
25 \\
25 \\
4 \\
4 \\
5 \\
0.6\end{array}$ & \begin{tabular}{r}
0.6 \\
.0 \\
.4 \\
.2 \\
.1 \\
.0 \\
.0 \\
.0 \\
\hdashline.- \\
\end{tabular} \\
\hline $1312 \ldots$ & 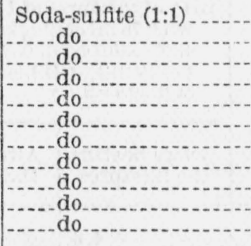 & $\begin{array}{r}1.2 \\
0.2 \\
.2 \\
1.6 \\
0.9 \\
1.0 \\
1.2 \\
0.3 \\
.9 \\
.3 \\
.3\end{array}$ & $\begin{array}{l}2.4 \\
2.1 \\
1.5 \\
1.4 \\
1.3 \\
1.3 \\
1.1 \\
1.0 \\
0.8 \\
.5\end{array}$ & $\begin{array}{l}5.2 \\
4.9 \\
5.3 \\
5.5 \\
5.8 \\
5.9 \\
6.0 \\
6.4 \\
6.2 \\
6.6 \\
6.9\end{array}$ & $\begin{array}{l}4.6 \\
4.3 \\
4.8 \\
4.9 \\
5.1 \\
5.1 \\
5.3 \\
5.7 \\
5.5 \\
6.2 \\
6.4\end{array}$ & $\begin{array}{r}0.6 \\
.6 \\
.5 \\
.6 \\
.7 \\
.8 \\
.7 \\
.7 \\
.7 \\
.4 \\
.5\end{array}$ & $\begin{array}{r}188 \\
376 \\
108 \\
94 \\
63 \\
66 \\
40 \\
16 \\
26 \\
4 \\
3\end{array}$ & $\begin{array}{r}63 \\
126 \\
50 \\
32 \\
16 \\
13 \\
10 \\
4 \\
6 \\
2.5 \\
1.3\end{array}$ & $\begin{array}{r}0.3 \\
.6 \\
.2 \\
.0 \\
.0 \\
.0 \\
.0 \\
0\end{array}$ \\
\hline $\begin{array}{ll}23 \\
24 \\
25 \\
26 \\
27 \\
28 \ldots \ldots\end{array}$ & 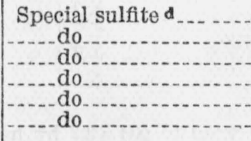 & $\begin{array}{l}1.9 \\
1.7 \\
1.1 \\
1.6 \\
1.1 \\
0.2\end{array}$ & $\begin{array}{l}2.3 \\
1.1 \\
0.8 \\
.8 \\
.6\end{array}$ & $\begin{array}{l}5.2 \\
5.6 \\
5.6 \\
6.1 \\
6.0 \\
6.9\end{array}$ & $\begin{array}{l}4.9 \\
5.3 \\
5.0 \\
5.7 \\
5.7 \\
7.2\end{array}$ & $\begin{array}{r}0.3 \\
.3 \\
.6 \\
.4 \\
.3\end{array}$ & $\begin{array}{r}63 \\
25 \\
75 \\
12 \\
10 \\
-\end{array}$ & $\begin{array}{r}63 \\
25 \\
25 \\
8 \\
10 \\
1\end{array}$ & $\begin{array}{r}0.1 \\
0 \\
\hdashline \\
\hdashline \\
\hdashline\end{array}$ \\
\hline $\begin{array}{ll}29 & \\
30 & \ldots \ldots \ldots \\
31 & \ldots \ldots \ldots\end{array}$ & \begin{tabular}{|c|} 
\\
Bleached sulfate do \\
do
\end{tabular} & $\begin{array}{r}1.0 \\
0.9 \\
.9 \\
.1\end{array}$ & $\begin{array}{l}2.3 \\
1.0 \\
0.7 \\
0\end{array}$ & $\begin{array}{l}5.2 \\
5.8 \\
6.4 \\
6.8\end{array}$ & $\begin{array}{l}4.9 \\
5.0 \\
6.0 \\
7.0\end{array}$ & $\begin{array}{r}0.3 \\
.8 \\
.4\end{array}$ & $\begin{array}{r}63 \\
84 \\
6\end{array}$ & $\begin{array}{r}63 \\
16 \\
4 \\
2\end{array}$ & $\begin{array}{r}0.2 \\
.0 \\
-0\end{array}$ \\
\hline
\end{tabular}

- These papers were made in the paper mill of the National Bureau of Standards.

- Percentage of alum was based on dry weight of solid materials in the chest.

- These papers contained no clay, all others listed contained 8 to 13 percent of clay.

d Pulps subjected to special purifying process by the manufacturers.

\section{EFFECT OF ACIDS FROM SOURCES OTHER THAN HYDROLYSIS OF ALUMINUM SALTS}

The correlation between the amounts of alum and the change in acidity upon heating may be interpreted in another manner-namely, that the amounts of any organic acids from cellulose, produced during heating by the action of the hydrogen ion resulting from hydrolysis, may increase with increasing proportions of alum. Although any organic acids produced would probably be weak, and their ionization would, therefore, as Browning and Ulm point out, be repressed by the strong acid, it has not yet been shown conclusively that they do not contribute to the measured $\mathrm{pH}$ when papers are extracted by heating.

The possibility must also be considered that hydrogen-ion retained by the fibers in the cold may be released during heating, since it will be shown that fibers extensively reduce the acidity of hydrolyzed alum solutions.

These points were investigated ${ }^{6}$ as follows. A solution of alum having a $\mathrm{pH}=4.7$, containing $0.0031 \mathrm{~g}$ per $70 \mathrm{ml}$, was heated as in the

\footnotetext{
- The experimental technique was the same as that previously described. See footnote 1.
} 
method of hot extraction for 1 hour at $100^{\circ} \mathrm{C}$. Upon cooling, the $\mathrm{pH}$ was found to be 3.7. Continued heating produced no further appreciable change in $\mathrm{pH}$. To $70-\mathrm{ml}$ portions of this hydrolyzed alum solution $1-\mathrm{g}$ portions of fibers from samples $11,22,28$, and 32 were added; and after 1 hour at room temperature, the $\mathrm{pH}$ of the mixtures was determined. The $\mathrm{pH}$ in every case was found to be much higher after than before the addition of the fibers to the previously heated solution, which showed that extensive decreases in the concentration of hydrogen ion had occurred. The results are given in table 2 , column 2 . It should be pointed out that this hydrolyzed alum solution remained at $\mathrm{pH}=3.7$ for several days when no fibers were added. Samples 11, 22,28 , and 32 were in the neutral region, as shown by the values for $\mathrm{pH}$-cold in column 5 , table 1 .

TABLE 2.-The behavior of a previously heated alum solution in the presence of neutral paper fibers

\begin{tabular}{|c|c|c|}
\hline \multirow[t]{2}{*}{ Sampleo } & \multicolumn{2}{|c|}{$\begin{array}{l}\mathrm{pH} \text { a of mixtures of } 1 \mathrm{~g} \text { of fibers } \\
\text { with } 70 \mathrm{ml} \text { of previously heated } \\
\text { alum solution ( } 0.0031 \mathrm{~g} \text { of alum } \\
\text { per } 70 \mathrm{ml}) . \mathrm{pH} \text { before addition } \\
\text { of fibers }=3.7 .\end{array}$} \\
\hline & $\begin{array}{l}\text { Before heating } \\
\text { the mixtures }\end{array}$ & $\begin{array}{l}\text { After heating } \\
\text { the mixtures }\end{array}$ \\
\hline $\begin{array}{l}\text { 11. Rag } \\
\text { 22. Soda sulfite } \\
\text { 28. Special sulfite } \\
\text { 32. Bleached sulfate }\end{array}$ & $\begin{array}{l}4.6 \\
5.2 \\
4.7 \\
5.0\end{array}$ & $\begin{array}{l}4.5 \\
5.3 \\
4.7 \\
5.0\end{array}$ \\
\hline
\end{tabular}

s All pH measurements were made at $25^{\circ} \mathrm{C}$.

- This solution had a $\mathrm{pH}=4.7$ before heating, and was further hydrolyzed to $\mathrm{pH}=3.7 \mathrm{by}$ heating for 1 hour at $100^{\circ} \mathrm{C}$, after which further heating caused no appreciable change in pH.

- The numbers are the same as in table 1, in which the samples are more fully described.

The four mixtures of hydrolyzed alum solution and fibers were then heated for 1 hour at $100^{\circ} \mathrm{C}$, cooled, and their $\mathrm{pH}$ values determined. The results, listed in column 3 of table 2 , reveal that little or no change in $\mathrm{pH}$ had occurred upon heating. Thus, since the hydrolyzed alum solution was known to contain relatively large amounts of hydrogen ion, as shown by the $\mathrm{pH}=3.7$, and since the fibers added were found to remove relatively large quantities of hydrogen ion from solution, the fact that subsequent heating of these mixtures resulted in no decrease in $\mathrm{pH}$ shows that no appreciable hydrogen ion was released by the fibers during the process. It appears, therefore, that such a release of hydrogen ion, if it occurs, cannot explain the $\mathrm{pH}$ changes encountered in the method of hot extraction.

Although the mixtures of hydrolyzed alum solution and fibers were even more acidic than usual, these higher concentrations of strong acid were not effective in producing organic acids during the heating process in amounts'arge enough to affect the measured $\mathrm{pH}$ appreciably.

\section{BEHAVIOR OF ALUM SOLUTIONS IN THE PRESENCE OF FIBERS}

Although the simple fact that alum solutions undergo decreases in $\mathrm{pH}$ upon heating makes it appear reasonable that the alum used in the manufacture of paper is responsible for the observed $\mathrm{pH}$ changes occurring when paper-water mixtures are heated, it remains to be 
shown that $\mathrm{pH}$ changes of the expected order of magnitude occur in alum solutions when fibers are present.

That the presence of fibers affects the hydrolytic process is shown by the following. From the details of a typical papermaking run, ${ }^{7}$ for example, paper 13, table 1 , in which 2.1 percent of alum was used, it can be calculated that $1 \mathrm{~g}$ of this finished paper would contain aluminum corresponding to $0.00091 \mathrm{~g}$ of alum, if selective retention of aluminum ion by the fibers in the beater and chest were neglected. The $\mathrm{pH}-$ cold of a mixture of $1 \mathrm{~g}$ of paper sample 13 with $70 \mathrm{ml}$ of distilled water was 4.9 , and the $\mathrm{pH}$ changed to 4.3 upon heating. When, however, 1-g portions of sample 22, containing the same fibers as paper 13 , and samples 11,28, and 32 (all largely free of alum) were added to $70-\mathrm{ml}$ portions of distilled water containing $0.00091 \mathrm{~g}$ of alum, the $\mathrm{pH}$ of the mixtures was much higher than 4.9 and the change in $\mathrm{pH}$, if any, upon heating was small. In the absence of fibers, an alum solution containing $0.00091 \mathrm{~g}$ per $70 \mathrm{ml}$ changed in $\mathrm{pH}$ from 4.9 to 4.1 upon heating. These results, given in table 3 , columns 2 and 3 , and footnote $\mathrm{a}$, indicate that the reactions involved in the $\mathrm{pH}$ changes upon heating alum solutions differ in the presence and absence of fibers. The results also indicate that the paper-water mixtures of table 1 behaved differently upon heating than the mixtures represented in table 3, which consisted of the same kind and amount of fibers, plus an amount of alum calculated upon the basis of no selective retention. of aluminum. When the amount of alum was increased to 10 times the calculated amount, the $\mathrm{pH}$ changes upon heating, shown in columns 6 and 7 , table 3 , became similar to those in table 1 . Such a large increase in the amount of alum, however, resulted in $\mathrm{pH}$ values which, even before heating, were abnormally low when contrasted with the values for $\mathrm{pH}$-cold of table 1 . Use of an intermediate amount of alum, columns 4 and 5 , resulted in initial $\mathrm{pH}$ values which were normal, but gave $\mathrm{pH}$ changes upon heating which were smaller than those usually found in papers of this $\mathrm{pH}$ range.

TABLE 3.-Behavior of previously unheated alum solutions in the presence of neutral paper fibers

\begin{tabular}{|c|c|c|c|c|c|c|}
\hline \multirow{3}{*}{ Sample } & \multicolumn{6}{|c|}{$\mathrm{pH}$ of mixtures of $1 \mathrm{~g}$ of fibers with $70 \mathrm{ml}$ of alum solutions } \\
\hline & \multicolumn{2}{|c|}{$\begin{array}{l}0.00091 \text { go falum per } \\
70 \mathrm{ml} \text {, pH before } \\
\text { addition of fi- } \\
\text { bers }=4.9 .\end{array}$} & \multicolumn{2}{|c|}{$\begin{array}{l}0.0031 \mathrm{~g} \text { of alum per } \\
70 \mathrm{ml} \text {. } \mathrm{pH} \text { before } \\
\text { addition of fi- } \\
\text { bers }=4.7 \mathrm{a}\end{array}$} & \multicolumn{2}{|c|}{$\begin{array}{l}0.0091 \mathrm{~g} \text { of alum per } \\
70 \mathrm{ml} \text {. pH before } \\
\text { addition of fi- } \\
\text { bers }=4.5^{\mathrm{a}}\end{array}$} \\
\hline & $\begin{array}{c}\text { Before } \\
\text { heating } \\
\text { mixtures }\end{array}$ & $\begin{array}{c}\text { After } \\
\text { heating b } \\
\text { mixtures }\end{array}$ & $\begin{array}{c}\text { Before } \\
\text { heating } \\
\text { mixtures }\end{array}$ & $\begin{array}{c}\text { After } \\
\text { heating } \\
\text { mixtures }\end{array}$ & $\begin{array}{c}\text { Before } \\
\text { heating } \\
\text { mixtures }\end{array}$ & $\begin{array}{c}\text { After } \\
\text { heating " } \\
\text { mixtures }\end{array}$ \\
\hline $\begin{array}{l}\text { 11. Rag } \\
\text { 22. Sulfite-soda } 28 \text { Special sulfite- } \\
\text { 32. Bleached sulfate- }\end{array}$ & $\begin{array}{l}5.9 \\
6.1 \\
5.8 \\
6.0\end{array}$ & $\begin{array}{l}6.1 \\
5.9 \\
6.0 \\
6.0\end{array}$ & $\begin{array}{l}4.9 \\
5.6 \\
5.0 \\
5.2\end{array}$ & $\begin{array}{l}4.6 \\
5.3 \\
4.7 \\
4.9\end{array}$ & $\begin{array}{l}4.5 \\
4.6 \\
4.5 \\
4.5\end{array}$ & $\begin{array}{l}\text { 3. } \\
4.2 \\
3.8 \\
3.9\end{array}$ \\
\hline
\end{tabular}

- The three solutions containing $0.00091,0.0031$, and $0.0091 \mathrm{~g}$ of alum per $70 \mathrm{ml}$ had $\mathrm{pH}$ values upon cooling of $4.1,3.7$, and 3.4 , respectively, after heating for 1 hour at $100^{\circ} \mathrm{C}$ without fibers present at any time.

All pH determinations were made at $25^{\circ} \mathrm{C}$.

'In this run the proportions were $32 \mathrm{cu}$ ft of water to $1.2 \mathrm{lb}$ of papermakers' alum and $58 \mathrm{lb}$ of fibers and clay. 1.5 parts by weight of machine water remain with each part of solid material until evaporated in the dryers. 
It is evident that the paper-alum-water mixtures just discussed differ in an important manner from the paper-water mixtures of table 1, in that, in the former, the $\mathrm{pH}$ changes upon heating are too small if the $\mathrm{pH}$-cold is normal, or the $\mathrm{pH}$-cold is too low if the changes in $\mathrm{pH}$ upon heating are normal. The cause of this difference will be considered in section V. The data presented thus far, however, allow some deductions to be made concerning the nature of the reactions occurring in the fiber-alum-water mixtures.

The data of table 3 raise three important questions: (1) Do fibers raise the $\mathrm{pH}$ of alum solutions by taking up only hydrogen ion, or is aluminum ion also retained and the acidity thus indirectly reduced? (2) Why is the rise in $\mathrm{pH}$ brought about by the addition of fibers large in the weak and hardly noticeable in the stronger solution of alum? (3) Why is the change in $\mathrm{pH}$ upon heating alum solutions much less in the presence of fibers than in their absence? A consideration of these three question follows.

In answer to question (1), relatively large amounts of unhydrolyzed aluminum ion are in the alum solutions before heating, at the three concentrations described in table 3. This was shown by the fact that heating greatly changed the $\mathrm{pH}$. The approximate amount of unhydrolyzed aluminum ion can be calculated from the data at hand. If the hydrolysis reaction is simply written as

$$
\mathrm{Al}^{+++}+3 \mathrm{HOH}=\mathrm{Al}(\mathrm{OH})_{8}+3 \mathrm{H}^{+}, 8
$$

the degree of hydrolysis is represented by the expression [measured concentration of hydrogen ion] - [concentration of hydrogen ion at complete hydrolysis.]

For the weakest of the three solutions the degree of hydrolysis is 11 percent, as calculated from the $\mathrm{pH}=4.9$, and the concentration of alum $=0.00091 \mathrm{~g} / 70 \mathrm{ml}=0.000117$ equivalent of alum or aluminum ion per liter. This shows that 89 percent of the aluminum ion was not hydrolyzed in the unheated solution. In the two stronger alum. solutions the proportion of unhydrolyzed aluminum ion was, of course, still greater.

The simplest expression for the hydrolysis constant for equation (1) as written is

$$
K_{\text {hydrolysis }}=\frac{\left(\mathrm{H}^{+}\right)^{3}}{\left(\mathrm{Al}^{+++}\right)}
$$

Substituting the three independent sets of data, for the three solutions, into this expression, the values obtained are $0.6 \times 10^{-10}, 0.7 \times 10^{-10}$ and $0.6 \times 10^{-10}$, in the order of increasing concentration of the three alum solutions of table 3 . The agreement may be considered as a measure of substantiation of the correctness of the hydrolysis equation as written.

Inasmuch as the removal of aluminum ion by the fibers would cause the reversal of the hydrolysis reaction, thus reducing the hydrogen ion concentration and raising the $\mathrm{pH}$, it is desirable to know if such a removal occurs.

\footnotetext{
${ }^{8}$ It is recognized that aluminum ion may hydrolyze in steps, but the equation as written represents the sum of these steps.
} 
Schwalbe ${ }^{9}$ showed that a sulfite pulp reduced the concentration of aluminum in an alum solution. His results were confirmed in the present work by the following experiments.

Samples of the basic materials, from which the papers listed in table 1 were made, were added in $1-\mathrm{g}$ portions to $70-\mathrm{ml}$ portions of alum solution containing $0.0031 \mathrm{~g}$ of $\mathrm{Al}_{2}\left(\mathrm{SO}_{4}\right)_{3} \cdot 18 \mathrm{H}_{2} \mathrm{O}$ per $70 \mathrm{ml}$. The basic materials, rather than the papers, were used, with the exception of sample 22 (see footnote c, table 1), in order to avoid large amounts of aluminum, present as clay in samples 11, 28, and 32 . These basic materials were found to have the same $\mathrm{pH}$ as the corresponding papers, with the exception of the special sulfite pulp, which was alkaline, but which became neutral upon washing twice with distilled water. They were found, furthermore, to have essentially the same effect upon the $\mathrm{pH}$ of alum solutions as the corresponding neutral papers, samples 11, 28, and 32. The aluminum in solution was determined with the sensitive colorimetric aurintricarboxylic acid method before and after the addition of the fibers. The sulfate was determined in the same solutions by precipitation with barium. ${ }^{10}$ The results given in table 4 show that extensive retention of aluminum ion occurred in all cases, since the changes shown are much larger than the indicated probable experimental error. The conclusions regarding the retention of sulfate ion are less definite, for these experimentally determined changes are as large as the experimental uncertainty; and it is not possible to decide from these data whether or not selective retention of sulfate ion occurs to a small extent. The data show, however, that aluminum sulfate is not retained as $\mathrm{Al}_{2}\left(\mathrm{SO}_{4}\right)_{3}$, since one part by weight of aluminum would therein be associated with over 5 parts by weight of sulfate. The slight gains, if real, in sulfate ion by the solutions are apparently due to the presence of sulfate, 0.05 to $0.15 \mathrm{mg}$, known ${ }^{11}$ to be present per gram of the usual fibers used in papermaking. The fact that aluminum ion is selectively retained is of major importance, since the amount of aluminum in paper, calculated solely upon the basis of concentrations in the beater, would not be large enough to explain the observed $\mathrm{pH}$ changes upon heating.

TABLE 4.--Retention of aluminum by fibers in an unheated alum solution a

\begin{tabular}{|c|c|c|c|c|}
\hline \multirow{2}{*}{ Fibers ( $1 \mathrm{~g}$ per $70 \mathrm{ml}$ of solution) } & \multicolumn{2}{|c|}{ Aluminum concentration } & \multicolumn{2}{|c|}{ Sulfate concentration } \\
\hline & $\begin{array}{l}\text { Before addi- } \\
\text { tion of fibers }\end{array}$ & $\begin{array}{l}\text { After addi- } \\
\text { tion of fibers }\end{array}$ & $\begin{array}{l}\text { Before addi- } \\
\text { tion of fibers }\end{array}$ & $\begin{array}{l}\text { After addi- } \\
\text { tion of fibers }\end{array}$ \\
\hline $\begin{array}{l}\text { A. New rags (half stuff) } \\
B \text {. Soda-sulfite (sample 22) } \\
C \text {. Special sulfite pulp } \\
D \text {. Bleached sulfate pulp. }\end{array}$ & $\begin{array}{r}m g \text { per } \gamma 0 \mathrm{ml} \\
0.27 \pm 0.02 \\
.27 \pm 0.02 \\
.27 \pm 0.02 \\
.27 \pm 0.02\end{array}$ & $\begin{array}{r}m g \text { per } \gamma 0 m l \\
0.17 \pm 0.02 \\
.10 \pm 0.02 \\
.03 \pm 0.02 \\
.02 \pm 0.02\end{array}$ & \begin{tabular}{|}
$m g$ per $70 m l$ \\
$1.3 \pm 0.2$ \\
$1.3 \pm 0.2$ \\
$1.3 \pm 0.2$ \\
$1.3 \pm 0.2$
\end{tabular} & $\begin{array}{r}m g \text { per } 70 \mathrm{ml} \\
1.6 \pm 0.2 \\
1.6 \pm 0.2 \\
1.2 \pm 0.2 \\
1.4 \pm 0.2\end{array}$ \\
\hline
\end{tabular}

a The alum solution was made by dissolving $0.0031 \mathrm{~g}$ of $\mathrm{cp} \mathrm{Al}_{2}\left(\mathrm{SO}_{4}\right)_{3} .18 \mathrm{H}_{8} \mathrm{O}$ per $70 \mathrm{ml}$. Upon analysis, the salt was found to have lost water and was better represented by the formula $\mathrm{Al}_{2}(\mathrm{SO})_{43} .16 \mathrm{H}_{2} \mathrm{O}$.

b All fibers were removed by filtration and dissolved organic matter was removed before the anaiyses. All $\mathrm{Al}(\mathrm{OH})_{3}$, not retained by the fibers but removed in the filtering process would constitute a small correction of the values of column 3 . The correction would probably be negligible, since not more than 5 percent of the aluminum would be present as $\mathrm{Al}(\mathrm{OH})_{\mathbf{3}}$, as shown by the value for the degree of hydrolysis for this concentration of aluminum sulfate.

- Carl G. Schwalbe, Z. angew. Chem. 37, 125 (1924).

10 The author thanks W. D. Mogerman and W. W. Walton of the Chemistry Division for cooperation in making these analyses.

11 R. C. Griffin, Paper Trade J. 90, 63.(May 1, 1930). 
The experiments just described do not, by themselves, indicate the form in which the aluminum is retained. It may be retained either (a) as completely hydrolyzed $\mathrm{Al}(\mathrm{OH})_{3}$ or (b) as unhydrolyzed $\mathrm{Al}^{+++}$ or as partially hydrolyzed $\mathrm{Al}(\mathrm{OH})^{++}$, for example, or both. In any case, the substances may be either physically adsorbed as such, or in some chemical combination with the organic or inorganic constituents of the fibers. Since physical adsorption would require that the sum of the ions, positive and negative, be zero, and since the concurrent removal of $\mathrm{SO}_{4} \approx$ has not been shown, the retention of $\mathrm{Al}^{+++}$as such, or its partially hydrolyzed forms, would be explainable by an ion exchange with the inorganic fiber constituents, calcium, for example. The mechanism of retention was not investigated.

If the aluminum were retained only as $\mathrm{Al}(\mathrm{OH})_{3}$, however, then practically all of the aluminum in the system, at least in the cases of $C$ and $D$, table 4 , would be in a completesy hydrolyzed condition before heating. The amount of unhydrolyzed aluminum, $\mathrm{Al}^{+++}$, would be then insufficient to explain the $\mathrm{pH}$ changes upon heating, as shown in table 3 , columns 4 and 5 . It appears, therefore, that the retention of hydrolyzable aluminum must occur.

These conclusions are necessary according to the theory which requires that the activity or mass-action effect of "solid" substances, in equlibrium with a solution, is unity, and that the amount of the solid phase present does not affect the ionic equilıbrium. This means that $\mathrm{Al}(\mathrm{OH})_{3}$ may be taken up by the fibers without upsetting the ionic equilibrium and without consequent formation of more $\mathrm{Al}(\mathrm{OH})_{3}$. Thus, only 11 percent or less of the aluminum in the three solutions under consideration could be removed from solution, if removed only as $\mathrm{Al}(\mathrm{OH})_{3}$. Table 4 shows this value to be greatly exceeded in all cases.

Additional evidence of the removal of aluminum ion by fibers is given in table 5. After fibers had been in contact with an alum solution for 1 hour, they were removed completely and the filtrates were heated for one hour at $100^{\circ} \mathrm{C}$, as usual, and cooled. Measurement of the final $\mathrm{pH}$ showed that the $\mathrm{pH}$ changes, and especially the changes in hydrogen-ion concentration of the filtrates upon heating, were much smaller than in the original solution, showing that hydrolyzable aluminum ion had been removed from solution. It should be stated that filtrates from mixtures of the fibers with distilled water alone, containing no alum, did not change in $\mathrm{pH}$ upon heating.

TABLE 5.-Changes in $\mathrm{pH}$ of the filtrates from fiber-alum-water mixtures

\begin{tabular}{|c|c|c|c|c|}
\hline Sample & $\begin{array}{c}\mathrm{pH} \text { of mixtures } \\
\text { of } 1 \mathrm{~g} \text { of abers } \\
+70 \mathrm{ml} \text { water } \\
+0.0031 \mathrm{~g} \text { of } \\
\text { alum. } \mathrm{pH} \\
\text { before addition } \\
\text { of fibers }=4.7^{\mathrm{s}}\end{array}$ & $\begin{array}{l}\mathrm{pH} \text { of } \\
\text { filtrate } \\
\text { before } \\
\text { heating }\end{array}$ & $\begin{array}{l}\mathrm{pH} \text { of } \\
\text { filtrate } \\
\text { after } \\
\text { heating }\end{array}$ & $\begin{array}{l}\text { Change in } \\
\mathrm{H}^{+} \text {-concen- } \\
\text { tration up- } \\
\text { on heating } \\
\text { filtrates }\end{array}$ \\
\hline 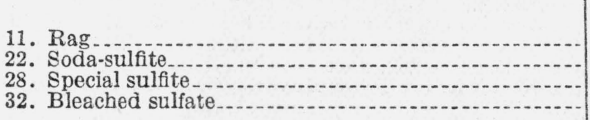 & $\begin{array}{l}4.9 \\
5.6 \\
5.0 \\
5.2\end{array}$ & $\begin{array}{l}4.7 \\
5.6 \\
4.8 \\
5.2\end{array}$ & $\begin{array}{l}4.1 \\
5.3 \\
4.5 \\
4.7\end{array}$ & $\begin{array}{r}\times 10^{-7} \\
600 \\
25 \\
155 \\
140\end{array}$ \\
\hline
\end{tabular}

- The solution after heating alone had a $\mathrm{pH}=3.7$. The change in $\mathrm{pH}$ from 4.7 to 3.7 represents a change in hydrogen ion concentration of $1800 \times 10^{-7}$ equivalents per liter.

All pH measurements were made at $25^{\circ} \mathrm{C}$. 
In answer to question (1), therefore experimental evidence shows that fibers selectively retain aluminum ion in alum solutions, thereby indirectly lowering the acidity. This occurs concurrently with the direct retention of hydrogen ion and the consequent direct lowering of acidity.

In answer to question (2), why fibers raise the $\mathrm{pH}$ of strong alum solutions less than that of weak solutions, it may be pointed out that the percentage of aluminum ion left in solution after retention by the fibers becomes larger with an increase in concentration of aluminum ion, inasmuch as retention cannot be expected to increase indefinitely with concentration in a strict proportion; that is, the fibers approach "saturation." As the total amount of alum was increased, table 3, the proportion left in solution after retention became larger, until, in the strongest solution, sufficient aluminum ion remained in solution to maintain the $\mathrm{pH}$ at the original value, except in the case of the soda-sulfite fibers. Even in the strongest solution as much as onefourth of the aluminum ion may have been retained by the fibers, since the hydrolysis relationship $\left(\mathrm{H}^{+}\right)=K \sqrt[3]{\left(\mathrm{Al}^{+++}\right)}$shows that large changes in the concentration of aluminum ion must occur before the $\mathrm{pH}$ changes become appreciable. Thus, in the more concentrated solutions of alum, the selective retention of aluminum ion may be considerable without affecting appreciably the cube root of the aluminum-ion concentration.

In answer to question (3), why $\mathrm{pH}$ changes upon heating alum solutions are larger in the absence than in the presence of fibers, there are two mechanisms which may be considered. Either the aluminum ion taken up by the fibers is not hydrolyzed by heating and only the aluminum in solution is, or else all, or most, of the aluminum ion hydrolyzes, but the hydrogen ion produced is subsequently taken up by the fibers. The latter appears more likely, however, for the values in table 2 , column 2, which were obtained by first hydrolyzing the aluminum ion and then reducing the acidity by adding fibers, are in good agreement with the values in table 3 , column 5 , which were obtained by heating the alum in the presence of fibers. This speaks in favor of the mechanism that all or most of the aluminum ion in the system is hydrolyzed upon heating, and the hydrogen ion produced is retained to an extent depending upon the nature of the fiber and upon the concentration of the acid.

\section{RETENTION PHENOMENA UNDER PAPERMAKING CONDITIONS}

The conditions of the experiments thus far described simulated conditions of paper extraction and were useful in showing the behavior of acid and alum occurring therein. The concentrations of materials during papermaking conditions are much different, however, than during extraction conditions. In a typical papermaking run, for a paper made with a medium amount of alum, 1.4 percent, for example, $1 \mathrm{~g}$ of fibers in the beater and chest is associated with $35 \mathrm{ml}$ of water containing $0.014 \mathrm{~g}$ of alum. This concentration is over three times as great as that of the strongest solution of alum referred to in the preceding section, which contained 10 times the amount of alum calculated on the basis of no retention, for extraction conditions of paper sample 13 of table 1 . Thus, the amount of aluminum retained under these papermaking conditions may be expected to be large. 
On the basis of the foregoing experiments, such large amounts of alum would be expected to result in much lower values for $\mathrm{pH}$-cold than those of table 1. In the foregoing experiments, however, distilled water was used,whereas the papers of table 1 were made, as usual, with tap water of $\mathrm{pH}=7.6$, to which much more alum must be added than to distilled water for a given resultant $\mathrm{pH}$. For example, $70 \mathrm{ml}$ of tap water containing $0.028 \mathrm{~g}$ of alum and $70 \mathrm{ml}$ of distilled water containing $0.0091 \mathrm{~g}$ of alum both have a $\mathrm{pH}=4.5$.

The proportions in a typical papermaking run were simulated with rag and with soda-sulfite paper fibers. One-gram portions of fibers were added to $35-\mathrm{ml}$ portions of tap water containing $0.014 \mathrm{~g}$ of alum each. After 1 hour at room temperature, the mixtures were filtered on a Büchner funnel and allowed to remain thereon until the pads contained $1.5 \mathrm{~g}$ of liquid, ${ }^{12}$ which corresponds to the moisture content of the paper sheet before it reaches the dryer. The pads were then mixed with $68.5 \mathrm{ml}$ of distilled water, to simulate extraction conditions, and the $\mathrm{pH}$-cold was determined after 1 hour at room temperature. The mixtures were then heated for 1 hour at $100^{\circ} \mathrm{C}$, cooled, and the pH-hot was determined. The results are given in table 6 , systems 2 and 3 , and show that paper extraction conditions for unsized papers were thus reproduced, in that both the $\mathrm{pH}$-cold and the change in $\mathrm{pH}$ upon heating were within the normal range.

TABLE 6.--pH relationships under papermaking and extraction conditions

\begin{tabular}{|c|c|c|}
\hline \multirow[b]{2}{*}{ System } & \multicolumn{2}{|c|}{$\mathrm{pH}$ values $\mathrm{s}$ of fibers } \\
\hline & $\begin{array}{l}\text { No. 11, } \\
\text { rag }\end{array}$ & $\begin{array}{l}\text { No. 22, } \\
\text { soda-sulfite } \\
\text { mixture }\end{array}$ \\
\hline $\begin{array}{l}\text { (1) } 1 \mathrm{~g} \text { of fibers }+35 \mathrm{ml} \text { of tap water containing } 0.014 \mathrm{~g} \text { of alum } \\
\text { (2) Fibers filtered, retaining } 1.5 \mathrm{~g} \text { of liquid; } 68.5 \mathrm{ml} \text { of distilled water added to }\end{array}$ & 4. 6 & 5.0 \\
\hline $\begin{array}{l}\text { (3) System (2) heated for } 1 \text { hour at } 100^{\circ} \mathrm{C} \text {, then cooled. } \\
\text { (4) } 1.5 \mathrm{~g} \text { of original solution of } 0.014 \mathrm{~g} \text { of alum in } 35 \mathrm{ml} \text { of tap water, added to }\end{array}$ & $\begin{array}{l}5.0 \\
4.4\end{array}$ & $\begin{array}{l}5.8 \\
5.0\end{array}$ \\
\hline (4) $68.5 \mathrm{ml}$ of distilled water containing $1 \mathrm{~g}$ of fibers & 6.4 & 6.5 \\
\hline (5) System (4) heated for 1 hour at $100^{\circ} \mathrm{C}$, then cooled & 6.4 & 6.1 \\
\hline
\end{tabular}

- All pH values measured at $25^{\circ} \mathrm{C}$.

The retention of aluminum ion under papermaking conditions was found to be considerable, as shown by the data in table 7, whereas that of sulfate ion was small, if it occurred at all. The amounts of aluminum and sulfate (see footnote 10) remaining in the fibers after exposure to tap water and to tap water containing alum were determined after igniting the materials. The ignition of the materials for sulfate analysis required special care. The materials were soaked in an excess of calcium chloride solution, and the mixture was evaporated to dryness and then ignited at $950^{\circ} \mathrm{C}$, at which temperature $\mathrm{CaSO}_{4}$ is stable. Blanks were run on all reagents. The presence of aluminum in the form of clay was again avoided by the use of the basic rag material from which sample 11 was made. The two last columns show that from one-third to almost one-half of the aluminum added to the beater is selectively retained, even in the absence of rosin size, whereas 96 percent of the aluminum would remain with the machine water if no selective retention occurred.

\footnotetext{
${ }^{12}$ Concentration of alum solution due to evaporation under these conditions was found to be negligible, since prolonging the time of the operation from the usual minute or so required to 2 minutes did not change the weight of the moist pad to an important extent; less than 5 percent of water was thereby lost.
} 
TABLE 7.-Retention phenomena under papermaking conditions

\begin{tabular}{|c|c|c|c|c|c|c|c|c|c|c|}
\hline \multirow[t]{2}{*}{ Fibers } & \multicolumn{2}{|c|}{$\begin{array}{l}\text { Gain for } 1 \mathrm{~g} \text { of fibers } \\
\text { exposed a to } 35 \mathrm{ml} \\
\text { of tap water con- } \\
\text { taining } 0.014 \mathrm{~g} \text { of } \\
\text { alum } \mathrm{l}\end{array}$} & \multicolumn{2}{|c|}{$\begin{array}{l}\text { Gain for } 1 \mathrm{~g} \text { of } \\
\text { fibers exposed } \\
\text { to } 35 \mathrm{ml} \text { of tap } \\
\text { water. No alum }\end{array}$} & \multicolumn{2}{|c|}{$\begin{array}{l}\text { Gain, net, due to } \\
\text { alum }\end{array}$} & \multicolumn{2}{|c|}{$\begin{array}{l}\text { Gain, if no } \\
\text { retention } \\
\text { occurred, } \\
\text { calculated } \\
\text { from weight } \\
\text { of solu- } \\
\text { tion s in } \\
\text { fibers after } \\
\text { filtration }\end{array}$} & \multicolumn{2}{|c|}{$\begin{array}{l}\text { Proportion } \\
\text { of sub- } \\
\text { stances } \\
\text { removed } \\
\text { from alum } \\
\text { solution } \\
\text { by fibers }\end{array}$} \\
\hline & $\mathrm{Al}$ & $\mathrm{SO}_{4}$ & $\mathrm{Al}$ & $\mathrm{SO}_{4}$ & $\mathrm{Al}$ & $\mathrm{SO}_{4}$ & $\mathrm{Al}$ & $\mathrm{SO}_{4}$ & $\mathrm{Al}$ & $\mathrm{SO}_{4}$ \\
\hline $\begin{array}{l}\text { A. New rags, } \\
\text { half stuff- }\end{array}$ & $\begin{array}{c}m g \mathrm{e} \\
0.45 \pm 0.01\end{array}$ & $\begin{array}{c}m g \\
0.5 \stackrel{m}{ \pm} .1\end{array}$ & $\begin{array}{c}m g \\
0.06 \stackrel{ \pm}{ \pm} 0.01\end{array}$ & $\begin{array}{c}m g \\
0.1 \stackrel{m g}{ \pm} 0.1\end{array}$ & $\begin{array}{c}m g \\
0.39 \stackrel{m}{ \pm} 0.01\end{array}$ & $\begin{array}{c}m g \\
0.4 \stackrel{ \pm}{ \pm} 0.1\end{array}$ & $\begin{array}{l}m g \\
0.05\end{array}$ & $\begin{array}{c}m g \\
0.3\end{array}$ & $\begin{array}{l}\text { Per- } \\
\text { cent } \\
\quad 33\end{array}$ & $\begin{array}{l}\text { Per- } \\
\text { cent }\end{array}$ \\
\hline $\begin{array}{l}\text { B. Soda-sulfite } \\
\text { No. } 22\end{array}$ & $.64 \pm 0.01$ & $.5 \pm 0.1$ & $.10 \pm 0.01$ & $.1 \pm 0.1$ & $.54 \pm 0.01$ & $.4 \pm 0.1$ & .05 & .3 & 45 & 6 \\
\hline
\end{tabular}

s Fibers remained in the solution 1 hour with constant stirring and were then filtered with suction until $1.5 \mathrm{~g}$ of solution remained with each gram of fibers.

b $0.014 \mathrm{~g}$ of alum=1.19 $\mathrm{mg}$ of aluminum and $6.3 \mathrm{mg}$ of sulfate.

- The experiments were actually performed with $2.5 \mathrm{~g}$ of fibers and corresponding amounts of liquid, for which the analytical precision was 0.02 and $0.2 \mathrm{mg}$ for aluminum and sulfate, respectively.

It was of interest to determine the $\mathrm{pH}$ relationships if no retention were allowed to take place. This was done as follows. $1.5 \mathrm{~g}$ of the original tap water-alum solution was directly added to $68.5 \mathrm{ml}$ of distilled water containing $1 \mathrm{~g}$ of fibers. This amount of alum would be the same as that in solution in the $1.5 \mathrm{~g}$ of liquid in the fibers, if retention of aluminum-ion by the fibers had not occurred. It was found, however, that not only was the $\mathrm{pH}$ of the mixtures made up by direct addition of alum solution much higher, but also the change in $\mathrm{pH}$ upon heating was much smaller, than in the mixture made up in the previous manner, by allowing $1.5 \mathrm{~g}$ of liquid to remain with the fibers. The results are given in the remainder of table 6 .

\section{EFFECT OF ROSIN UPON PH RELATIONSHIPS}

It has already been pointed out that the addition of rosin decreases not only the acidity of a paper, but also decreases the change in hydrogen-ion concentration upon heating the paper-water mixture, for papers made with 2 percent or more of alum. Since alum is always used in excess over the amount necessary to precipitate the rosin completely, this appears to be due to a reduction in the amount of available alum, presumably by the formation of insoluble aluminum resinate, as the following experiments show. Typical paper-water mixtures, referred to in table 1 , were filtered after they had stood for 1 hour at room temperature. These filtrates were then heated for 1 hour at $100^{\circ} \mathrm{C}$ and then cooled. The $\mathrm{pH}$ was determined before and after heating. A decrease in $\mathrm{pH}$ was found only for the filtrates from papers made with relatively large quantities of alum. The results are given in column 10 of table 1 . The effect of rosin upon the amount of alum leaving the paper fibers and dissolving into cold water is seen in the sample pairs 1 and 2,3 and 4 , and 12 and 13 .

Other effects of rosin upon the $\mathrm{pH}$ and $\mathrm{pH}$ changes during heating may, of course, occur, for no attempt has been made to extend the investigation to cover this point. It is to be observed, however, that if such effects exist, they are small, since no systematic difference between the behavior of sized and unsized papers in table 1 is noticeable, from the standpoint of $\mathrm{pH}$. The decreasing effect upon the 
acidity and acidity changes during heating, by increasing the amount of size used, is obviously not a direct function of the weakly acidic character of rosin itself.

\section{FUNDAMENTAL BASIS FOR CHOOSING BETWEEN HOT EXTRACTION AND COLD EXTRACTION}

It has been shown that the effect of hot extraction is to hydrolyze further the aluminum salts in the papers, thereby producing as much as 3 to 4 times the amount of hydrogen ion originally found in the cold extract. These large amounts of acid resulting from the hydrolysis of the aluminum salts obscure the presence of smaller amounts of other acids which may result from cooking or bleaching operations, or which may be present owing to acidic atmosphere.

Hot extraction has a further serious drawback. The aluminum salts in the papers may undergo partial hydrolysis, with the liberation of harmful acid, when they are stored or shipped under warm, humid conditions, or when the drying or other manufacturing processes were faulty. The amount of this acid cannot be measured by the method of hot extraction, since the heating process causes extensive further hydrolysis, irrespective of any partial hydrolysis which may already have occurred. The method of cold extraction, on the other hand, gives $\mathrm{pH}$ values corresponding to the hydrolysis equilibrium at room temperature; thus, any displacement of this equilibrium by previous higher temperatures will be measured. If the alum was already partially hydrolyzed by faulty storage or manufacturing conditions, the acid thus liberated should be and is measured in the unheated extract.

If the acidity of a paper, as it exists under conditions of use, can be employed as a measure of its permanence, and it appears that this is true, then the method of cold extraction gives a much closer measure of the significant $\mathrm{pH}$ values of papers than do the more complicated methods now in general use.

Washington, October 20, 1939. 